\title{
Ecological status for Ratapani wild life sanctuary, Raisen (MP) India
}

\begin{abstract}
The baseline study was conducted for the evaluation of the floral and faunal biodiversity of the terrestrial as well as aquatic environment of the study area, it comprises of total 5reserved forest and 3 protected forest including Ratapani Wildlife Sanctuary falls Dist.-Raisen, Madhya Pradesh, India. It is strongly recommended to prepare the conservation plan for schedule -1 Fauna (listed 9 animals and 1 bird) and it is ensure to implement the conservation plan during construction and operation phase of railway track. Moreover, there is an urgent need of public awareness for the importance of wildlife, as illegal hunting, killing or capturing of wild animals was recorded from locals living in the forest and nearby villagers.
\end{abstract}

Keywords: faunal biodiversity, floral biodiversity, nature conservancy, reserve forest, wildlife sanctuary
Volume 2 Issue 2 - 2018

\author{
Ashok K Rathoure \\ Ecology \& Biodiversity Expert, Ecosystem Resource \\ Management Pvt. Ltd., India
}

\author{
Correspondence: Ashok K Rathoure, Ecology \& Biodiversity \\ Expert, Eco Chem Sales \& Services, Ecosystem Resource \\ Management Pvt. Ltd., Surat Gujarat, India, \\ Email asokumr@gmail.com
}

Received: December 08, 2017| Published: April 12, 2018

\section{Introduction}

Plants and animals are more susceptible to environmental stress. A change in the composition of biological communities is reflected by a change in the distribution pattern, frequency, density and abundance of natural species of flora and fauna existing in the ecosystem. These changes over a span of time can be quantified and related to the existing environmental factors. Natural flora and fauna are important features of the environment. They are organized into natural communities and are sensitive to outside influences. Integrating ecological thinking into the planning process is urgent need in the context of deterioration of natural environment, which is unwanted but direct consequence of development.

\section{Methodology}

Study area $(10 \mathrm{~km}$ radius w.r.t. to railway track passing through sanctuary) comprises of reserved and protected forest including wildlife sanctuary. There are five reserved forest and 3 protected forest including Ratapani Wildlife Sanctuary (Figure 1). The primary objective of survey was to describe the floral and faunal communities within the study area. The sampling plots for floral inventory were selected randomly in the suitable habitats. ${ }^{1-6}$ The methodology adopted for faunal survey involve random survey, opportunistic observations, diurnal bird observation, active search for reptiles, faunal habitat assessment, active search for scats and foot prints, animal call, and review of previous studies. The aim was to set baselines in order to monitor and identify trends after the commissioning of the cargo handling activity. Emphasis has been placed on presence of endemic species, threatened species if any present in the study area. The qualitative study has been carried out only. The listed of villages covered for survey is presented in Table 1 and the detailed method and parameters covered for the said study has been highlighted in Table 2.

Table I Sensitivity of the study area

\begin{tabular}{llll}
\hline S. no. & Area/Track/Zone & Name of forest/hot spots & Remarks \\
\hline I & Rail track & $\begin{array}{l}\text { Railway Track (2 lines) of Length } \\
26.70 \text { km passing through wildlife } \\
\text { sanctuary/reserve forest. }\end{array}$ & $\begin{array}{l}\text { There is one more line (third) is proposed parallel to } \\
\text { Existing (2 lines - up \& down) railway track passing through } \\
\text { Wildlife Sanctuary. }\end{array}$ \\
2 & Obedullahganj & Chakla RF & \\
3 & Obedullahganj & Diwattiaya PF & \\
4 & Obedullahganj & Gohar Ganj RF & Reserved and protected forest fall in the study area, majorly \\
5 & Obedullahganj & Obedullahganj PF & \\
6 & Obedullahganj & Obedullahganj RF & \\
7 & Budani & Budani PF & \\
8 & Budani & Budani RF & Ramnagar RF \\
9 & Budani & &
\end{tabular}

Desktop literature review was conducted to identify the representative spectrum of threatened species, population and ecological communities listed by IUCN, WCMC, ZSI, BSI and Indian
Wild life Protection Act, $1972 .^{3-6,13-24}$ The status of individual species was assessed using the revised IUCN/SSC category system..$^{25-31}$ 
Table 2 Mode of Data collection and Parameters considered during the Survey

\begin{tabular}{|c|c|c|c|c|c|}
\hline S. no. & Aspect/s & Data & Mode of data collection & Parameters monitored & Remarks \\
\hline I. & $\begin{array}{l}\text { Terrestrial } \\
\text { Ecology }\end{array}$ & $\begin{array}{l}\text { Primary data } \\
\text { collection }\end{array}$ & $\begin{array}{l}\text { By Field Survey, Hutto et } \\
\text { al., }{ }^{7} \text { Welsh, }{ }^{8} \text { Thommpson et } \\
\text { al., }{ }^{9} \text { Welsh et al., }{ }^{10} \text { Allen et } \\
\text { al.," }{ }^{\prime \prime} \text { Misra, }{ }^{12}\end{array}$ & $\begin{array}{l}\text { For Floral diversity, Vegetation } \\
\text { measurements: } \\
\text { Tree, Shrub, Herbs, Grasses, Climbers, } \\
\text { Cultivated plants in the study area, } \\
\text { Floristic composition of the study area, } \\
\text { Medicinal plants of the study area, Status } \\
\text { of the forest, their category in the study } \\
\text { area, Rare and endangered flora in the } \\
\text { study area. Endemic plants in the study } \\
\text { area. } \\
\text { For Fauna in the study area: } \\
\text {-Reptiles, } \\
\text {-Amphibians, } \\
\text {-Birds, } \\
\text {-Fresh water fishes } \\
\text {-Mammals, } \\
\text {-Butterflies. } \\
\text {-Fungal species } \\
\text {-Rare and Endangered fauna in the study } \\
\text { area, } \\
\text {-Endemic fauna in the study area, } \\
\text {-Wild life and their conservation } \\
\text { importance in the study area. }\end{array}$ & $\begin{array}{l}\text { Random survey, opportunistic } \\
\text { observations, diurnal bird } \\
\text { observation, active search } \\
\text { for reptiles, faunal habitat } \\
\text { assessment, active search } \\
\text { for microhabitat, scats, } \\
\text { foot prints, animal call, } \\
\text { pug marks, debarking sign, } \\
\text { Nesting, Claws, Dung, etc. } \\
\text { and information from local } \\
\text { villagers. }\end{array}$ \\
\hline 2. & & $\begin{array}{l}\text { Secondary data } \\
\text { collection }\end{array}$ & $\begin{array}{l}\text { I. Barkhera Range } \\
\text { and Budani } \\
\text { Range Forest } \\
\text { Division } \\
\text { II. Data of Fisheries } \\
\text { department. } \\
\text { III. Literature like } \\
\text { research papers, } \\
\text { books published } \\
\text { by research/ } \\
\text { academic } \\
\text { Institutions. }\end{array}$ & $\begin{array}{l}\text { Interpretation of secondary data for } \\
\text { Ecological Sensitive Areas such as } \\
\text { national forests, wild life sanctuaries, } \\
\text { lakes, ravines, hills, hillocks and reserve } \\
\text { forest, vegetation, type, importanceetc. }\end{array}$ & $\begin{array}{l}\text { Bentham \& Hooker, }{ }^{13} \\
\text { Hunter, }{ }^{14} \text { Dixit, }{ }^{3} \text { Ghosh } \\
\text { et al., }{ }^{15} \text { Lushington, }{ }^{16} \\
\text { Wilson \& Reeder, }{ }^{17} \text { Bird } \\
\text { Life International, }{ }^{18} \text { Bird } \\
\text { Life International, }{ }^{99,20} \\
\text { Wilson \& Reeder, }{ }^{4} \text { Bird Life } \\
\text { International, }{ }^{21} \text { Kumar \& } \\
\text { Srivastava, }{ }^{22} \text { Kumar, }{ }^{5} \text { Kumar } \\
\text { et al.., }{ }^{6} \text { Kumar \& Aggarwal. }{ }^{23,24} \\
\text { The status of individual } \\
\text { species was assessed using the } \\
\text { revised IUCN/SSC category } \\
\text { system. }{ }^{25-31}\end{array}$ \\
\hline 3. & $\begin{array}{l}\text { Evaluation } \\
\text { of ecological } \\
\text { sensitivity }\end{array}$ & Secondary & Review and Discussion & $\begin{array}{l}\text { Wild life importance, Floral Endemicity, } \\
\text { Faunal Endemicity, State of Terrestrial } \\
\text { vegetation, State of wet land vegetation, } \\
\text { Mangrove vegetation, Conservation } \\
\text { importance, Legal status (National park, } \\
\text { Wild life sanctuary, Reserve forest, } \\
\text { Wetlands, Agricultural lands) Lakes / } \\
\text { reservoirs/dam, Natural lakes and } \\
\text { Swamps, Breeding ground of Migratory } \\
\text { and Residential birds. }\end{array}$ & - \\
\hline
\end{tabular}

\section{Results and discussion}

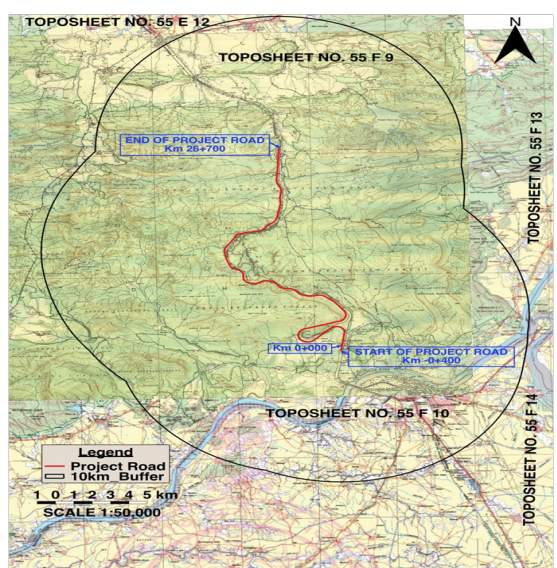

Figure I Study area Map on Toposheet (SOI).

\section{Terrestrial floral and faunal biodiversity}

Biological diversity (biodiversity) encompasses the variety of life forms viz. fungus, algae, plants, animals, etc. Rock shelters increase/ decrease in algal/fungal growth in the forest of Ratapani wildlife sanctuary. Agro-ecological regions by the National Bureau of Soil Survey \& Land Use Planning (NBSS \& LUP) have been delineated. Delineation of agro-climatic zones based on soil, water, rainfall, temperature etc. is the first essential step for sustainable production. The National Bureau of Soil Survey \& Land Use Planning (NBSS \& LUP) came up with twenty agro-ecological zones based on the growing period as integrated criteria of effective rainfall, soil groups, delineated boundaries adjusted to district boundaries with a minimal number of regions. Subsequently, these twenty agro-ecological zones were sub-divided into 60 sub-zones. As per the map provided in Figure 
2, the study area fall under Central Highlands (Malwa, Bundelkhand and Eastern Satpura) which represents tropical dry deciduous forest cat $5 \& 3$ with hot sub humid climate with black and red soil (length of cropping period is 150-180 days) favorable for mustard, wheat, pulses. Vegetation in the Malwa Plateau is tropical dry forest, with scattered teak (Tectona grandis L. f.) forests. The other main trees are Butea spp., Bombax spp., Anogeissus spp., Acacia spp., Buchanania spp. and Boswellia spp. The shrubs or small trees include species of Grewia spp., Ziziphus mauritiana Lamk., Casearia spp., Prosopis spp., Capparis spp., Woodfordia spp., Phyllanthus spp., and Carissa spp.. The Malwa plateau is considered to be an extension of the Deccan Traps and was formed at the end of Cretaceous period. Black, Brown and Bhtatori or stony soil is abundant in the Malwa Plateau.
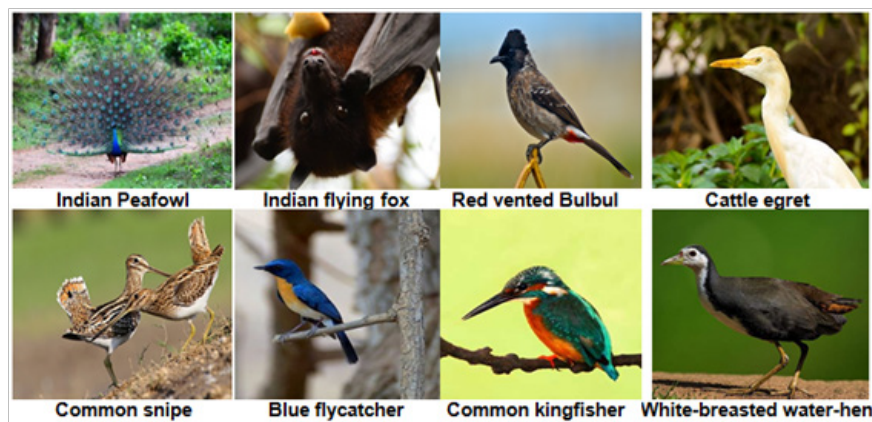

Figure 2 Avifauna in the study area.

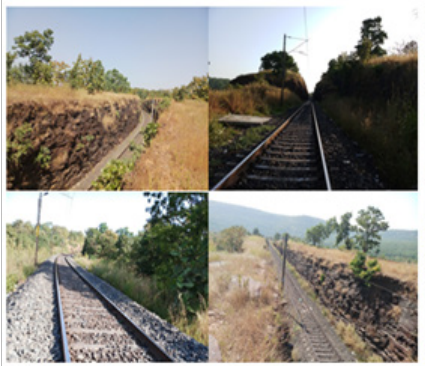

Railway track passing through WLS

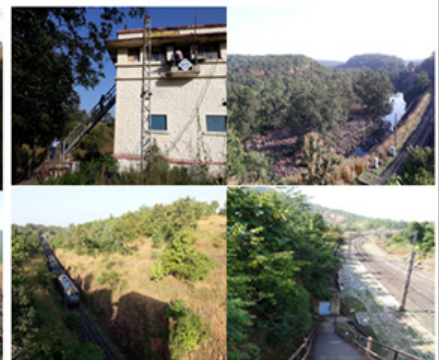

Train passing on Railway track in WLS
Figure 4 View of Rail Track passing through wild life sanctuary at different location.
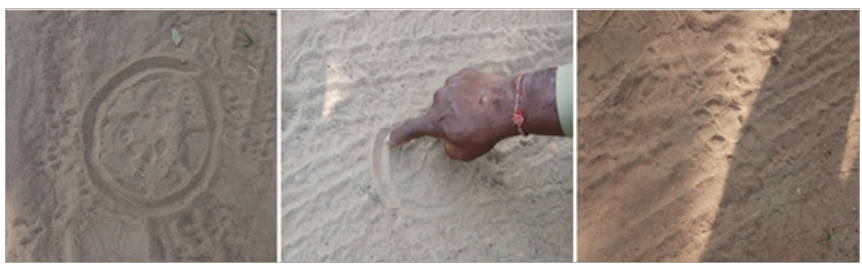

Figure 6 Pug marks of Tiger Movement in Wildlife sanctuary.

\section{Floral diversity of the study area}

The objective of this floral inventory of the study area is to provide necessary information on floristic structure in the study area for formulating effective management and conservation measures. The climatic, edaphic and biotic variations with their complex interrelationship and composition of species, which are adapted to these
The black soil requires less irrigation because of its high capacity for moisture retention. The other two soil types are lighter and have a higher proportion of sand. Ratapani Wildlife Sanctuary contains 129 tree species, 73 herbs and shrubs species, 33 climbers and parasites, 35 grasses and bamboo species, 35 mammals, 205 birds, 14 fish, 33 reptiles and 10 species of amphibians have been recorded in Ratapani Wildlife Sanctuary. The major crop in the study area is Rabi (winter crops) and Kharif (summer crops); this cropping pattern depends on water from Narmada River. The forest land is involved in the railway track. There is no any major crop in the forest area, only maize was observed at some places where tribal living. The location of wildlife sanctuary shown in the map of Madhya Pradesh is shown in Figures 3-9.

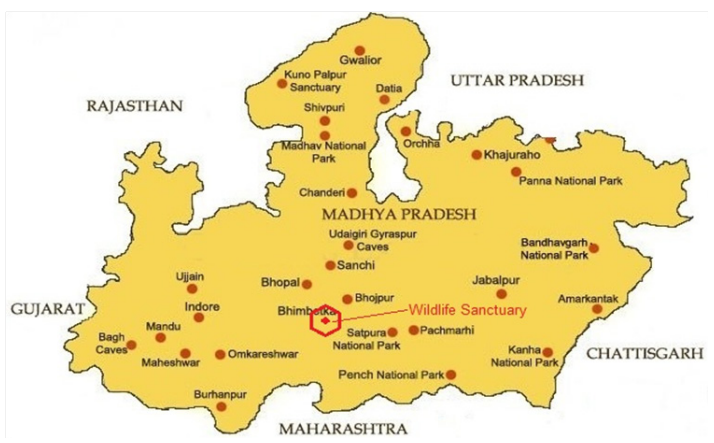

Figure 3 Location of Wildlife Sanctuary in Map of Madhya Pradesh.

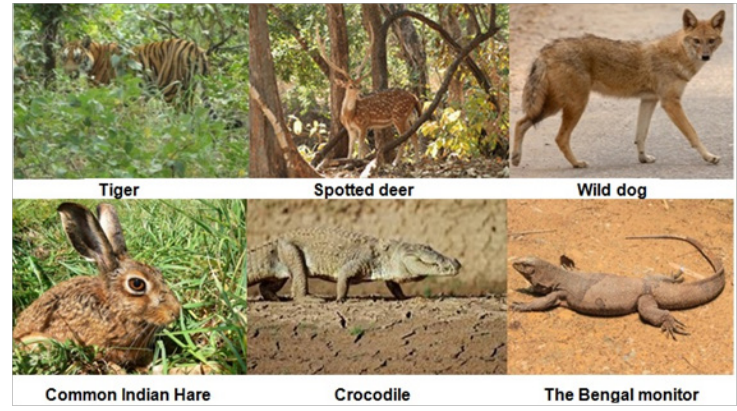

Figure 5 Wildlife Presence in the Forest (WLS).

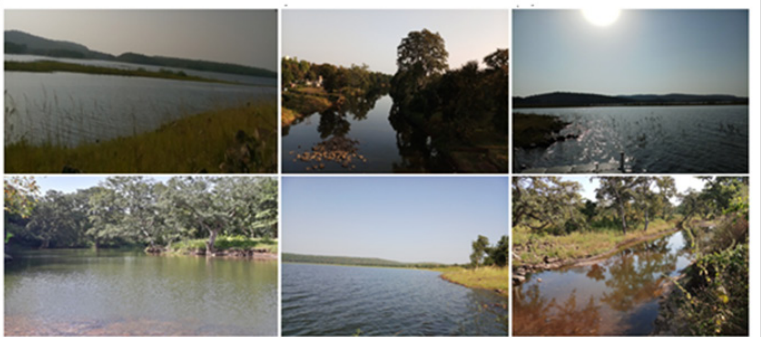

Figure 7 Aquatic Habitat of the Study Area.

variations, have resulted in different vegetation cover, characteristic of each region. ${ }^{32}$ The tree species, herbs, shrubs, climbers and major crops, were documented during this base line study. ${ }^{33,34}$

Trees and shrubs: A tree is a perennial plant with an elongated stem or trunk, supporting branches and leaves in most species. Trees tend to be long-lived, some reaching several thousand years old. While a shrub or bush is a small to medium-sized woody plant. They are 
distinguished from trees by their multiple stems and shorter height and are usually less than $6 \mathrm{~m}(20 \mathrm{ft})$ tall. The dominant trees in the study area are Tectona grandis L.f. (Sagaun/teak), Butea monosperma (Lam.) Taub. (Palas), Acacia nilotica (ITIS) (Babool), Mangifera indica
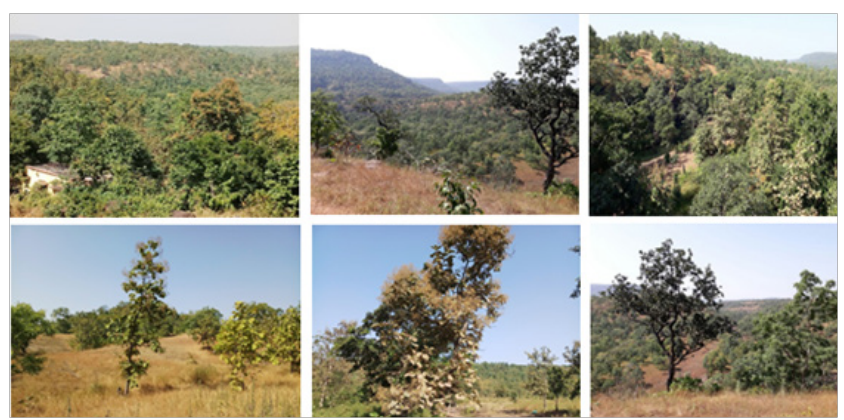

Figure 8 Tree Distribution and pattern in the Forest.

Table 3 Trees in the Study area (Natural Vegetation)
L. (Aam), Pongamia glabra L. (Karanj), Zizyphus mauritiana (Lamk) (Ber). A total 101 species of trees belong to 37 families are enumerated from the study area (Table 3).

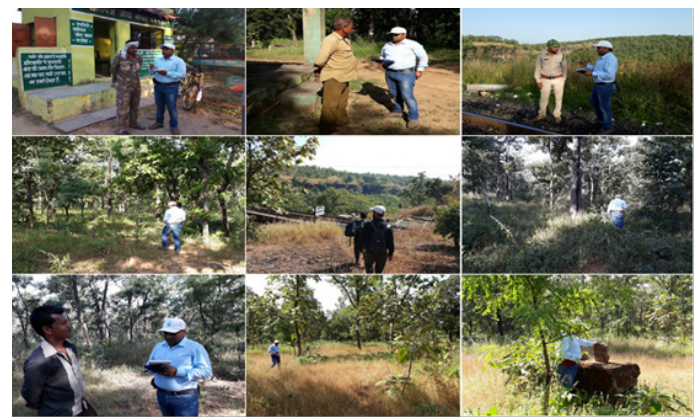

Figure 9 Glimpses of Local information and Confirmation from Locals/Villagers.

\begin{tabular}{|c|c|c|c|}
\hline S. no. & Family & Vernacular name & Botanical name \\
\hline I. & \multirow{3}{*}{ Anacardiaceae } & Chironji & Buchanania lanjan \\
\hline 2. & & Aam & Mangifera indica \\
\hline 3. & & Jhingan & Lannea coromendelica \\
\hline 4. & \multirow{3}{*}{ Anonaceae } & Ashok & Polyalthia longifolia \\
\hline 5. & & Kari & Saccopetalum tomentosum \\
\hline 6. & & Sitafal & Anona squamosa \\
\hline 7. & Apocynaceae & Dudhi/Karayja & Wrightia tinctoria \\
\hline 8. & Bignoniaceae & Padar & Sterospermum suaveolens \\
\hline 9. & \multirow{2}{*}{ Bixaceae } & Kakai & Flacourtia ramontchi \\
\hline 10. & & Galgal & Cochlospermum religiosum \\
\hline II. & \multirow{2}{*}{ Boraginaceae } & Datraga & Ehretia laevis, \\
\hline 12. & & Lasoda & Cardia myxa \\
\hline 13. & \multirow{2}{*}{ Burseraceae } & Keked & Garuga pinnata \\
\hline 14. & & Salai & Boswellia serrata \\
\hline 15. & Capparidaceae & Barna & Crataeva unilocularis \\
\hline 16. & \multirow[t]{3}{*}{ Celastraceae } & Jamrasi & Elaeodendron glaucum \\
\hline 17. & & Arjun & Terminalia arjuna \\
\hline 18. & & Dhavada & Anogeissus latifolia \\
\hline 19. & \multirow[t]{3}{*}{ Combreteceae } & Bahera & Terminalia belerica \\
\hline 20. & & Kardhai & Anogeissus pendula \\
\hline 21. & & Saaj & Terminalia tomentosa, \\
\hline 22. & Cornaceae & Akol & Ailangium lamarchii \\
\hline 23. & \multirow{2}{*}{ Ebenaceae } & Tendu & Diospyros melanoxylon \\
\hline 24. & & Bhaktendu & Diospyros cordifolia \\
\hline 25. & \multirow{6}{*}{ Euphorbiaceae } & Aanvla & Emblica officinalis \\
\hline 26. & & Kasai & Bridelia retusa \\
\hline 27. & & Thuar & Euphorbia neriifolia \\
\hline 28. & & Ratanjot & Jatropha curcus \\
\hline 29. & & Roli & Mallotus philippinensis \\
\hline 30. & & Sahand & Euphorbia nivulia \\
\hline 31. & Lauraceae & Maida lakdi & Litsea glutinosa \\
\hline
\end{tabular}




\begin{tabular}{|c|c|c|c|}
\hline S. no. & Family & Vernacular name & Botanical name \\
\hline 32. & \multirow[t]{13}{*}{ Lecythidaceae } & Kumbhi/Kalindi & Careya arborea \\
\hline 33. & & Amaltas & Cassia fistula \\
\hline 34. & & Anjan & Hardwickja binata \\
\hline 35. & & Asta & Bauhinia racemose \\
\hline 36. & & Imli & Tamarindus indica \\
\hline 37. & & Karanj & Pongamia glabra \\
\hline 38. & & Kachnar & Bauhinia variegata \\
\hline 39. & & Kalasiris & Albizzia lebbek \\
\hline 40. & & Keyolar & Bauhinia spp. \\
\hline 41. & & Kheir & Acacia catechu \\
\hline 42. & & Khejra & Prosopis juliflora \\
\hline 43. & & Gulmohar & Delonix regia \\
\hline 44. & & Chhekur & Prosopis spicigera \\
\hline 45. & \multirow[t]{13}{*}{ Fabaceae } & Chhichva & Albizzia odoratissima \\
\hline 46. & & Tinsa & Ougeinia dalbergiodes \\
\hline 47. & & Dhovin & Dalbergia paniculata \\
\hline 48. & & Palas & Butea monosperma \\
\hline 49. & & Pagra & Eythrina suberosa \\
\hline 50. & & Babool & Acacia nilotica \\
\hline 51. & & Bijasaal & Pterocarpus marsupium \\
\hline 52. & & Renja & Acacia leucophloea \\
\hline 53. & & Safed siris & Albizzia procera \\
\hline 54. & & Safed khair & Acacia ferruginae \\
\hline 55. & & Sehra & Bauhinia retus \\
\hline 56. & & Bhisom & Delbergia latifolia \\
\hline 57. & & Sissu & Delbergia sissoo \\
\hline 58. & Lythraceae & Seja & Lagerstroemia parviflora \\
\hline 59. & \multirow{3}{*}{ Malvaceae } & Pula & Kydia calycina \\
\hline 60. & & Kullu & Sterculia lanceolata \\
\hline 61. & & Neem & Azadirachta indica \\
\hline 62. & \multirow[t]{4}{*}{ Meliaceae } & Bakain & Melia azedarach \\
\hline 63. & & Rohan & Soymida febrifuga \\
\hline 64. & & Gular & Fiaus glomerate \\
\hline 65. & & Pakar & Ficus infectoria \\
\hline 66. & \multirow{4}{*}{ Moraceae } & Paraspeepal & Fias retusa \\
\hline 67. & & Peepal & Ficus religiosa \\
\hline 68. & & Bargad/vad & Fursbengdensis \\
\hline 69. & & Bhahtoot & Morus laevigates \\
\hline 70. & Moringaceae & Sahjana & Moringa pterygosperma \\
\hline 71. & \multirow{2}{*}{ Myrtaceae } & Jamun & Syzygium cuminii \\
\hline 72. & & Gum tree & Eucalyptus sp. \\
\hline 73. & Oleaceae & Mokha & Schrebera swietenioidas \\
\hline 74. & Arecaceae & Khajoor & Phoenix humilis \\
\hline
\end{tabular}




\begin{tabular}{|c|c|c|c|}
\hline S. no. & Family & Vernacular name & Botanical name \\
\hline 75. & \multirow{2}{*}{ Rhamnaceae } & Ghont & Zyphus xylopyra \\
\hline 76. & & Ber & Zizyphus mauratiana \\
\hline 77. & \multirow{9}{*}{ Rubiaceae } & Aal & Morinda tintoria \\
\hline 78. & & Kem & Mitragyana parvifolia \\
\hline 79. & & Dikamali & Gardenia licisa \\
\hline 80. & & Tilwan & Wendlandia exserts \\
\hline 81. & & Papra & Gardenia latifolia \\
\hline 82. & & Feitara & Gardenia turgida \\
\hline 83. & & Bhawarsal & Hymenodictyon excelsum \\
\hline 84. & & Haldu & Adina cordifolia \\
\hline 85. & & Lokhandi & Ixora parviflors \\
\hline 86. & \multirow{4}{*}{ Rutaceae } & Keth & Feronia Limonia \\
\hline 87. & & Bel & Aegle marmelos \\
\hline 88. & & Bilsena & Limonia Crenculata \\
\hline 89. & & Meethneem & Murrasya koenigii \\
\hline 90. & Salmaliaceae & Semal & Salmalia malabarcum \\
\hline 91. & Salvadoraceae & Peelu & Salvadora oleodides \\
\hline 92. & \multirow{2}{*}{ Sapindaceae } & Kusum & Schleiehera trijuga \\
\hline 93. & & Reetha & Sapindus laurifolius \\
\hline 94. & \multirow{2}{*}{ Sapotaceae } & Mahuva & Madhuca indica \\
\hline 95. & & Molsari & Mimusops elangi \\
\hline 96. & Simaroubaceae & Maharukh & Ailanthus excelsa \\
\hline 97. & Tiliaceae & Dhaman & Grewia tiliaefolia \\
\hline 98. & \multirow[t]{2}{*}{ Ulmaceae } & Chirol & Holoptelea integrifolia \\
\hline 99. & & Gamari & Gmelina arborea \\
\hline 100. & \multirow[t]{2}{*}{ Verbenaceae } & Morpaye & Vitex peduncularis \\
\hline 101. & & Sagaun/Teak & Tectona grandis \\
\hline
\end{tabular}

Herbs: Total 37 herbaceous species belongs to 29 family (agricultural Table 4. crops not included) were recorded from the study area enlisted in Table 4 List of Herbaceous species observed in the Study area

\begin{tabular}{llll}
\hline S. no. & Family & Vernacular name & Scientific name \\
\hline I. & Acanthaceae & Maruadona & Strobilanthes callosus \\
2. & Amaranthaceae & Chirchita & Achyranthes aspera \\
3. & Anacardiaceae & Adusa & Adhatoda vasica \\
4. & Apocynaceae & Karonda & Carissa spinarum \\
5. & Kurchi & Holarrhena antidysenterica \\
6. & Asciepiadaceae & Oak & Calotropdis gigantea \\
7. & Berberidaceae & Sarkata & Argemone mexicana \\
8. & Cactaceae & Nagfani & Optuttia dillenii \\
9. & Capparidanceae & Heens & Capparis horrida \\
10. & Kareel & Capparis aphylla \\
II. & Celastraceae & Bekal & Gymnosporta montana \\
12. & Asteraceae & Gokhuru & Xanthium aspera \\
13. & Euphorbiaceae & Jhondharli & Antidesina ghacsehilla \\
14. & & Chakhetan & Fluggca microcarpa \\
15. & & Tarwar & Cassia auriculata \\
16. & Fabaceae & Chumui & Mimosa rubicaulis \\
17. & & Chipti & Desmodium pulchellum \\
\hline
\end{tabular}




\begin{tabular}{llll}
\hline S. no. & Family & Vernacular name & Scientific name \\
\hline 18. & Fabaceae & Nirgud & Indigolera pulchella \\
19. & & Tovara & Cassia tora \\
20. & & Kala Bansa & Colebrookea oppositifolia \\
21. & Lamiaceae & Puwar & Vitex negundo \\
22. & & Kora & Pogostemon plectranthoides \\
23. & Lythraceae & Dhawai & Woodfordia floribunda \\
24. & Malyaceae & Banakpas & Thespesia lampus \\
25. & Myrsinaceae & Babrang & Embelia robusta \\
26. & Myrtaceae & Jamun & Eugenia heyncana \\
27. & Rhamnaceae & Jharberi & Zityphtis rotundifolia \\
28. & Rutaceae & Ratanjot & Clausena pantaphylla \\
29. & Salicaceae & Bansa & Salix tetrasperama \\
30. & Sapindaceae & Khareta & lodonoca visocosa \\
31. & Sterculiaceae & Marorfali & Helicteres isora \\
32. & Tamaricaceae & Jhau & Tamarix dioica \\
33. & Tiliaceae & Gursakari & Grewia hirsuta \\
34. & Bandi & Grewia scabrophylla \\
35. & Verbenaceae & Harsingar & Nyctanthes arbortristis \\
36. & Vitaceae & Hathi kand & Leea macrophylla \\
37. & Zygophyllaceae & Hingota & Balanites roxburghiii \\
\hline & & & \\
\hline
\end{tabular}

Creepers: Total 19 Creepers species belongs to 7 families (agricultural Table 5. crops not included) were recorded from the study area enlisted in

Table 5 List of Creepers observed in the Study area

\begin{tabular}{|c|c|c|c|}
\hline S. no. & Family & Vernacular name & Scientific name \\
\hline I. & \multirow{2}{*}{ Asclepiadaceae } & Gudmar & Gymnema sylvestris \\
\hline 2. & & Chikti & Marsdenia tenacissima \\
\hline 3. & \multirow{2}{*}{ Combretaceae } & Hathi Sandan & Combretum ovalifolia \\
\hline 4. & & Peevarvel & Combreturn decandrum \\
\hline 5. & \multirow[t]{5}{*}{ Dioscoreaceae } & Baichandi & Dioscorea daemons \\
\hline 6. & & Kavach & Mucuna pruriens \\
\hline 7. & & Karanj & Caesalpinia sepiaria \\
\hline 8. & & Gaanj & $\begin{array}{l}\text { Melletia } \\
\text { auriculata }\end{array}$ \\
\hline 9. & & Rathi & Abrus precatorius \\
\hline 10. & \multirow[t]{5}{*}{ Leguminosae } & Gurar & Acacia cassia \\
\hline 11. & & Palas Bel & Butea superba \\
\hline 12. & & Mahul & Bauhinia vahlii \\
\hline 13. & & Ravni & Acacia pennata \\
\hline 14. & & Nasbel & Spatholobus roxbarghii \\
\hline S. no. & Family & Vernacular name & Scientific name \\
\hline 15. & \multirow{2}{*}{ Liliaceae } & Agnishikha & Gloriosa superba \\
\hline 16. & & Satavari & Asparagus racemosa \\
\hline 17. & Menispermaceae & Giloy & Tinospora cordifolia \\
\hline 18. & \multirow[b]{2}{*}{ Rhamnaceae } & Makoy & Zizyphus oenoplia \\
\hline 19. & & Kevti & Ventilago calyculata \\
\hline
\end{tabular}

Grasses and parasitic plant: Total 22 grass species belongs to Gramineae family (agricultural crops not included) and fourparasitic plants belongs to threefamilies were recorded from the study area enlisted in Table 6. 
Table 6 List of Grasses and parasitic plant observed in the Study area

\begin{tabular}{|c|c|c|c|}
\hline S. no. & Family & Vernacular name & Scientific name \\
\hline I. & & Kus & Eragrostis nees \\
\hline 2. & & Kusal & Heteropogon contortus \\
\hline 3. & & Kunda & Ischaemum pilosum \\
\hline 4. & & Kaus & Saccharum spointaneum \\
\hline 5. & & Kush & Desmostachya bipinnata \\
\hline 6. & & Khas & Vetiveria zizaniodes \\
\hline 7. & & Gararu & Coix gigentea \\
\hline 8. & & Gadela & Coix lacrymajobi \\
\hline 9. & & Guner & Themada quadrivalvis \\
\hline 10. & & Chikula & Chrysopogon montanus \\
\hline II. & & Chhir & Imperata cylindrica \\
\hline 12. & Gramineae & Dub & Cynodon dactylon \\
\hline 13. & & Poniya & Schima sulcatum \\
\hline 14. & & Phuli & Apluda varis \\
\hline 15. & & Phusel & Iseilema laxum \\
\hline 16. & & Phooli & Apluda mutica \\
\hline 17. & & Baas & Dendracalamus strictus \\
\hline 18. & & Katang baas & Bambusa bamboos \\
\hline 19. & & Basu & Sorghum halepense \\
\hline 20. & & Bhurbushi & Eragrostis tenella \\
\hline 21. & & Marvel & Dichanthium annulatum \\
\hline 22. & & Gather & Bothriochloa pertusa \\
\hline 23. & & Sen & Cenchrus ciliaris \\
\hline \multicolumn{4}{|c|}{ Parasitic plant } \\
\hline 24. & Coonvolvulaceae & Amarbel & Cuscuta reflexa \\
\hline 25. & Orchidaceae & Archid & Vanda tessellata \\
\hline 26. & \multirow{2}{*}{ Loranthaceae } & Banda & Vascum nepalense \\
\hline 27. & & Bada & Dendrophthoe falcata \\
\hline
\end{tabular}

\section{Cultivated plants in the study area}

The prevalent cropping systems of this area are the cumulative results of past and present decisions by individuals; these decisions are usually based on experience, tradition, expected profit, personal preferences and resources, and so on. The crop occupying the highest percentage of the sown area of this region is taken as the major crop and all other possible alternative crops, which are sown in this region either as substitutes of the base crop in the same season or as the crops which fit in the rotation in the subsequent season, are considered as minor crop. It is observed that, the different parts of the study area were practicing different crop pattern based on the season and availability of irrigation facility. The general crop patterns practiced in the study area were maize, wheat and others.

Major horticultural crops: Plantation of Chikku (Manilkara zapota), Kela (Musa sp.) Papaya (Carica papaya), Amla (Phyllanthus emblica) and mango trees (Mangifera indica) were observed at some localities. Mango trees (Mangifera indica) were observed adjacent to the residential area and also along the road side at almost all villages.

Major vegetable corps: The major vegetables grown in the study area were:

i. Bhindi (Abelmoschus escelentus)

ii. Brinjal (Ringana Solanum melongena)

iii. Cabbage (Brassica oeraceae)

iv. Tomato (Lycopersicon lycopersicum)

v. Karela (Momordica charantia)

e. Pulses: The pulses cultivated in this region were Gram (Cicer arietinum); Mug (Vigna acontifolia), Arhar (Cajanus cajan). 
Rare and endangered flora in the study area: The International Union for Conservation of Nature (IUCN) Red List is the world's most comprehensive inventory of the global conservation status of plant and animal species. It uses a set of criteria to evaluate the extinction risk of thousands of species and subspecies. These criteria are relevant to all species and all regions of the world. With its strong scientific base, the IUCN Red List is recognized as the most authoritative guide to the status of biological diversity. Out of 17000 species of higher plants known to occur in India, nearly 614 higher plant species were evaluated by IUCN. Among them 247 species are under threatened category (IUCN, 2008). As per list of 2012, plants seemed to be the most threatened life form with 60 species being listed as Critically Endangered and 141 as Endangered in India. Among the enumerated flora in the study area, none of them were assigned any threat category by Red data book of Indian Plants ${ }^{35-40}$ and Red list of threatened Vascular plants. ${ }^{31}$

Endemic plants of the study area: De Candolle (1855), Swiss botanist, first used the concept of Endemic, which is defined as an area of a taxonomic unit, especially a species which has a restricted distribution or habitat, isolated from its surrounding region through geographical, ecological or temporal barriers. Out of 17000 species of known flowering plants of India nearly 5000 species are said to be endemic. Nearly 58 genera and 1932 taxa are found to be endemic to peninsular India. ${ }^{41-49}$

The flora of India is one of the richest in the world due to the country's wide range of climate, topology, and environment. There are over 15,000 species of flowering plants in India which account for $6 \%$ of all plant species in the world. Many plant species are being destroyed, however, due to their prevalent removal. Roughly $1 / 4$ of all plant species in the world are at risk of being endangered or going extinct. The combination of global warming and habitat destruction is the sole reason for the disappearance of many plants. Though there are thousands of interesting and unusual plants, here are some common plants which have become rare and endangered species in the past 30 years due to habitat destruction.

Among recorded plant species nonecan be assigned the status of endemic plant of this region. Tree community (Species-area) curves based on phytosociology fitted to the data may show unnatural shapes, with leveling-off or even decrease in sampling sizes higher than average. This distortion can be explained by the subjective, preferential method of field sampling used in phytosociology. When making releves in species-poor vegetation, one probably tends to use larger plots in order to include more species. The reason for this may be that a higher number of species gives a higher probability of including presumed diagnostic species, so that the releve can be more easily classified in the Braun-Blanquet classification system. This may has at least two consequences: in phytosociological data bases species-poor vegetation types are underrepresented or releves are artificially biased towards higher species richness; the suitability of phytosociological data for species richness estimation is severely limited.

Status of the forest, their category in study area: According to the Champion and Seth, the forest tropical high deciduous of this region fall into the following categories:

a. 5A / CIII- Southern tropical dry Deciduous Mixed Forest.

b. 5A / DSI- Southern tropical dry Deciduous Scrub (Degradation Stage). c. 5 / DS4- Southern tropical dry Deciduous Forest (Degradation Stage).

Following are the forest (WLS/RF/PF) has been recorded for the study area.

I. Ratapani Wild Life Sanctuary

II. Chakla RF

III. Diwattiaya PF

IV. Gohar Ganj RF

V. Obedullahganj PF

VI. Obedullahganj RF

VII. Budani PF

VIII.Budani RF

IX. Ramnagar RF

\section{Ratapani wildlife sanctuary}

Ratapani Wildlife Sanctuary spreads over an area of $1201.29 \mathrm{~km}^{2}$ is located in Raisen District in the State of Madhya Pradesh. Ratapani Wildlife Sanctuary is extremely rich in flora and fauna and harbours a number of endemic species. Ratapani Wildlife Sanctuary is rich in biodiversity. These wildlife areas are classified into semi-arid wildlife zone - IV B Gujarat Rajputana under Roger and Pawar classification. The sanctuary is inhabited by all the usual animals of the region, such as tiger (Panthera tigris) leopard (Panthera pardus), wolf (Canis lupus), Jackal (Canis aureus), Indian fox (Vulpes bengalensis), Striped hyena (Hyaena hyaena) Sloth bear (Melursus ursinus) among carnivores and spotted deer (Axis axis), Sambhar (Cervus unicolor), Nilgai (Boselaphus tragocamelus), Chinkara (Gazella bennetti), wild pig (Sus scrofa), Chowsingha (Tetracerus quadriconis) and blackbuck (Antelope cervicapra), amongst herbivores. Apart from these, crocodiles/gharials can also be seen in Ratapani Wildlife Sanctuary. Ratapani Wildlife Sanctuary contains 129 tree species, 73 herbs and shrubs species, 33 climbers and parasites, 35 grasses and bamboo species, 35 mammals, 205 birds, 14 fish, 33 reptiles and 10 species of amphibians have been recorded in Ratapani Wildlife Sanctuary (Table 7 \& Table 8)

Table 7 Coordinates for Ratapani Wildlife Sanctuary

\begin{tabular}{lll}
\hline Corners & Latitude (N) & Longitude (E) \\
\hline A & $23^{\circ} 2^{\prime} 21.742^{\prime \prime}$ & $77^{\circ} 20^{\prime} 9.817^{\prime \prime}$ \\
B & $22^{\circ} 48^{\prime} 58.759^{\prime \prime}$ & $77^{\circ} 25^{\prime} 39.132^{\prime \prime}$ \\
C & $23^{\circ} 8^{\prime} 30.593^{\prime \prime}$ & $78^{\circ} 16^{\prime} 31.158^{\prime \prime}$ \\
D & $23^{\circ} 17^{\prime} 47.545^{\prime \prime}$ & $78^{\circ} 12^{\prime} 19.342^{\prime \prime}$
\end{tabular}

Table 8 Coordinates for EcoSensitive Zone of Ratapani Wildlife Sanctuary

\begin{tabular}{lll}
\hline Corners & Latitude (N) & Longitude (E) \\
\hline A & $23^{\circ} 2^{\prime} 12.670^{\prime \prime}$ & $77^{\circ} 19^{\prime} 2.020^{\prime \prime}$ \\
B & $22^{\circ} 48^{\prime} 24.792^{\prime \prime}$ & $77^{\circ} 25^{\prime} 38.686^{\prime \prime}$ \\
C & $23^{\circ} 8^{\prime} 28.575^{\prime \prime}$ & $78^{\circ} 17^{\prime} 7.044^{\prime \prime}$ \\
D & $23^{\circ} 18^{\prime} 53.787^{\prime \prime}$ & $78^{\circ} 12^{\prime} 43.135^{\prime \prime}$ \\
\hline
\end{tabular}

It is necessary to conserve and protect the area to the extent and boundaries of which is specified in paragraph 1 of this notification, 
around the protected area of Ratapani Wildlife Sanctuary as Ecosensitive zone from ecological, environmental and biodiversity point of view and to prohibit industries or class of industries and their operations and processes in the said Eco-sensitive Zone.

Extent and boundaries of eco-sensitive zone: The extent of Ecosensitive Zone is one kilometer in the revenue area and two kilometer in the surrounding forest area from the boundary of Ratapani Wildlife Sanctuary. The area of Eco sensitive Zone is $546.52 \mathrm{~km}^{2}$ which has 72 villages (Table 9).

\section{Activities prohibited or to be regulated within the Eco-sensitive Zone}

All activities in the Eco sensitive Zone shall be governed by the provisions of the Environment (Protection) Act, 1986 (29 of 1986) and the rules made there under including the Coastal Regulation Zone (CRZ), 2011 and the Environmental Impact Assessment (EIA) Notification, 2006 and other applicable laws including the Forest (Conservation) Act, 1980 (69 of 1980), the Indian Forest Act, 1927 (16 of 1927), the Wildlife (Protection) Act 1972 (53 of 1972), and amendments made thereto and be regulated in the manner specified.

\section{Prohibited activates in eco sensitive zone}

Commercial mining: All new and existing (minor and major minerals), stone quarrying and crushing units are prohibited with immediate effect except for meeting the domestic needs of bona fide local residents including digging of earth for construction or repair of houses and for manufacture of country tiles or bricks for housing and for other activities. The mining operations shall be carried out in accordance with the order of the Hon'ble Supreme Court dated $4^{\text {th }}$ August, 2006 in the matter of T.N. Godavarman Thirumulpad vs. UOI in W.P.(C) No.202 of 1995 and dated 21.04.2014 in the matter of Goa Foundation Vs. UOI in W.P.(C) No.435 of 2012.

Setting of industries causing pollution (water, air, soil, noise, etc.): No new industries and expansion of existing polluting industries in the Eco-sensitive zone shall be permitted. Only non-polluting industries shall be allowed within ESZ as per classification of Industries in the Guidelines issued by Central Pollution Control Board in February 2016, unless so specified in this notification. In addition, non-polluting cottage industries shall be promoted.

Establishment of major hydroelectric project: Prohibited (except as otherwise provided) as per applicable laws.

Use or production or processing of any hazardous substances: Prohibited (except as otherwise provided) as per applicable laws:

Discharge of untreated effluents in natural water bodies or land area: Prohibited (except as otherwise provided) as per applicable laws:

Setting of new saw mills: No new or expansion of existing saw mills shall be permitted within the Eco-sensitive Zone.

Setting up of brick kilns: Prohibited (except as otherwise provided) as per applicable laws.

Use of polythene bags: Prohibited (except as otherwise provided) as per applicable laws.

Commercial use of firewood: Prohibited (except as otherwise provided) as per applicable laws.
New wood based industry: Prohibited (except as otherwise provided) as per applicable laws.

Fishing: Prohibited (except as otherwise provided) as per applicable laws.

Table 9 List of Villages on Eco Sensitive Zone of Ratapani Wildlife Sanctuary

\begin{tabular}{|c|c|c|}
\hline S. no. & Division & Village \\
\hline I. & \multirow{26}{*}{ Bhopal } & Rabiyawad \\
\hline 2. & & Vurthi \\
\hline 3. & & Prabadhan \\
\hline 4. & & Stahphan \\
\hline 5. & & Punha \\
\hline 6. & & Banpur \\
\hline 7. & & Alampur \\
\hline 8. & & Amchha Kalan \\
\hline 9. & & Amchha Khurd \\
\hline 10. & & Ankalpur \\
\hline II. & & Baheria \\
\hline 12. & & Bamhori \\
\hline 13. & & Bamuila \\
\hline 14. & & Bansgahan \\
\hline 15. & & Bari \\
\hline 16. & & Bhiyanpur \\
\hline 17. & & Bineka \\
\hline 18. & & Biptanagar \\
\hline 19. & & Bithori \\
\hline 20. & & Borpani \\
\hline 21. & & Chora Kamraura \\
\hline 22. & & Damdongri \\
\hline 23. & & Dehgaon \\
\hline 24. & & Dhabla \\
\hline 25. & & Dimria \\
\hline 26. & & Ghana Kalan \\
\hline 27. & \multirow[t]{23}{*}{ Obedullahganj } & Ghatpipaliya \\
\hline 28. & & Ghoti \\
\hline 29. & & Goripura \\
\hline 30. & & Jalkhera \\
\hline 3 ।. & & Jatanpur \\
\hline 32. & & Jet \\
\hline 33. & & Karakbani \\
\hline 34. & & Karitalai \\
\hline 35. & & Kesalwara \\
\hline 36. & & Khari \\
\hline 37. & & Kumhariya \\
\hline 38. & & Kumri \\
\hline 39. & & Mahwakheri \\
\hline 40. & & Mokalwara \\
\hline $4 \mathrm{I}$. & & Nishankhera \\
\hline 42. & & Nishankhera \\
\hline 43. & & Niwari \\
\hline 44. & & Panagar \\
\hline 45. & & Ratanpur \\
\hline 46. & & Tajpura \\
\hline 47. & & Thanwari Ghatkheri \\
\hline 48. & & Udayagiri \\
\hline 49. & & Umariya \\
\hline
\end{tabular}


Table Continued.

\begin{tabular}{|c|c|c|}
\hline S. no. & Division & Village \\
\hline 50. & & Bandral \\
\hline 51. & & Jaipura \\
\hline 52. & & Jamgarh \\
\hline 53. & Raisen & Madhamau \\
\hline 54. & & Padariya \\
\hline 55. & & Samnapur \\
\hline 56. & & Amargarh \\
\hline 57. & & Amdoh \\
\hline 58. & & Babariakhal \\
\hline 59. & & Bardha \\
\hline 60. & & Barijhiri ka Pathar \\
\hline 61. & & Budhni \\
\hline 62. & & Imaliya \\
\hline 63. & & Johliapur \\
\hline 64. & Sehore & Karkadehri \\
\hline 65. & & Kheri \\
\hline 66. & & Maljhar \\
\hline 67. & & Midghat \\
\hline 68. & & Nadiakheda \\
\hline 69. & & Neemwalakheda \\
\hline 70. & & Patni \\
\hline 7I. & & Sirwara \\
\hline 72. & & Yaarnagar \\
\hline
\end{tabular}

\section{Faunal biodiversity of study area}

For the documentation of the faunal biodiversity of the study area with respect to birds, reptiles, amphibians, and butterfly species, a baseline survey had been conducted.

Birds: The sighting of bird species was very lass during the study period. The most commonly spotted bird species of this area were Eurasian Collared-Dove, Cattle Egret, Red-wattled Lapwing, Intermediate Egret, Rock Pigeon, Chestnut-headed Bee-eater, Bank Myna and Common Myna. Water birds are common near to Ratapani Lake. The Indian Peafowl was observed which is listed as schedule -I as per IWPA, 1972 and others listed as schedule IV as per IWPA, 1972.

Total 1,224 bird species reliably recorded from India, together with their status categories. In total there are 1219 extant native species including migrants and vagrants (but excluding 3 species now known to be extinct in the country and 2 introduced species). There are 923 breeding species (911 residents, plus 12 suspected residents). IUCN evaluated 1254 bird species from India and categorized 77 species as threatened (13 species as critically endangered, 10 species as Endangered and 54 species as Vulnerable). No one sighted birds were evaluated as near threatened by IUCN ${ }^{25}$ and Bird Life International. ${ }^{15}$ A taxon is Near Threatened, when it has been evaluated against the criteria but does not qualify for Critically Endangered, Endangered or Vulnerable categories, but is close to qualifying or is likely to qualify for a threatened category in the near future. List of schedule -1 as per Wild life Protection Act 1972, species is given in the Table 10. Systematic account of the birds in the study area with the status of occurrence is given in the Table 11.

Table I 0 Schedule -I Bird(s) of Study Area

\begin{tabular}{|c|c|c|c|}
\hline Species & As IWPA I 972 & IUCN & CITES \\
\hline $\begin{array}{l}\text { Indian Peafowl } \\
\text { (Pavo cristatus, } \\
\text { Linnaeus, I758) }\end{array}$ & $\begin{array}{l}\text { Schedule I; Part } \\
\text {-III; II }\end{array}$ & $\begin{array}{l}\text { Least } \\
\text { Concern ver } 3.1\end{array}$ & Not listed \\
\hline
\end{tabular}

Butterflies from the study area: Butterflies from three families observed during the present study are documented in the Table 12 .

Herpetofauna: In amphibian group, thetoads were sighted during the study period. The reptiles Common Garden Lizard, House Gecko, Fan-Throated Lizard, Common rat Snake, Indian Monitor, Crocodile, etc. were observed in the region is given in the Table 13.

Mammals: The wild mammals observed other than the domesticated ones are given in the Table 14.

Domestic Animals: The domestic animals viz. dog, cow, buffalo, goat, sheep and chicken observed in the study area.

Insects like Wasps, Honeybees and Signature spider was also recorded.

Fisheries: Narmada River is Major River in the study area, one lake i.e. Ratapani Water Lake and Natural Drain (Gadariya Nala) are the water bodies in the study area. The fishes observed in study area are listed in Table 15 .

Rare and endangered fauna of study area: The IUCN Red List is the world's most comprehensive inventory of the global conservation status of plant and animal species. It uses a set of criteria to evaluate the extinction risk of thousands of species and subspecies. These criteria are relevant to all species and all regions of the world. With its strong scientific base, the IUCN Red List is recognized as the most authoritative guide to the status of biological diversity. IUCN, (2008) has evaluated 1976 animal species from India, among them 313 have in recognized as threatened species. Among them one species is considered as extinct, while 44 species are in critically endangered (CR) category, 88 is in endangered category (EN), while 181 is considered as vulnerable (VU). Wild Life (Protection) Act, 1972, amended on $17^{\text {th }}$ January 2003 , is an Act to provide for the protection of wild animals, birds and plants and for matters connected therewith or ancillary or incidental thereto with a view to ensuring the ecological and environmental security of the country. Total 10 species of the sighted fauna were given protection under Schedule $-\mathrm{I}$ by the Indian Wild Life (Protection) Act, 1972 listed in Table 16 (Figure 10). 
Table I I Systematic Lists of Birds in the Study Area with Status

\begin{tabular}{|c|c|c|c|c|}
\hline $\begin{array}{l}\text { S. } \\
\text { No. }\end{array}$ & Family & Vernacular name & Scientific name & Status \\
\hline I. & \multirow{6}{*}{ Accipitridae } & Black-winged kite & Elanus caeruleus (Desfontaines, I789) & $\mathrm{R}$ \\
\hline 2. & & Black kite & Milvus migrans (Boddaert, I783) & $\mathrm{R}$ \\
\hline 3. & & Shikra & Accipiter badius (Gmelin, I788) & $\mathrm{V}$ \\
\hline 4. & & Changeable hawk-eagle & Nisaetus cirrhatus (Gmelin, I788) & O \\
\hline 5. & & Tawny eagle & Aquila rapax (Temminck, I828) & $E$ \\
\hline 6. & & Crested serpent eagle & Spilornis cheela (Latham, I790) & $E$ \\
\hline 7. & \multirow[t]{2}{*}{ Alaudidae } & $\begin{array}{l}\text { Ashy-crowned sparrow- } \\
\text { lark }\end{array}$ & Eremopterix griseus (Kaup, I836) & $\mathrm{R}$ \\
\hline 8. & & Pied kingfisher & Ceryle rudis (Linnaeus, I758) & $\mathrm{R}$ \\
\hline 9. & \multirow{3}{*}{ Alcedinidae } & Common kingfisher & Alcedo atthis (Tucker and Health 1994) & $\mathrm{R}$ \\
\hline 10. & & White-throated kingfisher & Halcyon smyrnensis (Linnaeus, 1758) & $\vee$ \\
\hline II. & & Black-capped kingfisher & Halcyon pileata (Boddaert, I783) & $\mathrm{R}$ \\
\hline 12. & \multirow{4}{*}{ Anatidae } & Eurasian teal & Anas crecca (Linnaeus, I758) & O \\
\hline 13. & & Northern shoveller & Anas clypeata (Linnaeus, I758) & O \\
\hline 14. & & Cotton teal & $\begin{array}{l}\text { Nettapus coromandelianus (Gmelin, } \\
\text { I789) }\end{array}$ & $\mathrm{R}$ \\
\hline 15. & & Knob-billed duck & Sarkidiornis melanotos (Pennant, I769) & $\mathrm{R}$ \\
\hline 16. & \multirow{2}{*}{ Apodidae } & Alpine swift & Tachymarptis melba (Linnaeus, I758) & $\mathrm{R}$ \\
\hline 17. & & Little swift & Apus affinis (JE Gray, I830) & $\mathrm{R}$ \\
\hline 18. & \multirow{5}{*}{ Ardeidae } & Grey Heron & Ardea cinerea (Linnaeus, 1758) & $\mathrm{R}$ \\
\hline 19. & & Indian pond heron & Ardeola grayii (Sykes, I832) & $\mathrm{R}$ \\
\hline 20. & & Cattle egret & Bubulcus ibis (Linnaeus, I758) & $\mathrm{R}$ \\
\hline 21. & & Little egret & Egretta garzetta (Linnaeus, I766) & $\mathrm{R}$ \\
\hline 22. & & Large egret & Egretta garzetta(Linnaeus, I766) & $\mathrm{R}$ \\
\hline 23. & \multirow[t]{2}{*}{ Artamidae } & Ashy woodswallow & Artamus fuscus (Vieillot, I8I7) & $\vee$ \\
\hline 24. & & Small minivet & $\begin{array}{l}\text { Pericrocotus cinnamomeus (Linnaeus, } \\
\text { 1766) }\end{array}$ & W \\
\hline 25. & \multirow[t]{2}{*}{ Campephagidae } & Scarlet minivet & Pericrocotus speciosus (Latham, 1790) & V \\
\hline 26. & & Black-faced cuckooshrike & $\begin{array}{l}\text { Coracina novaehollandiae (Gmelin, JF, } \\
\text { I789) }\end{array}$ & $\mathrm{V}$ \\
\hline 27. & Caprimulgidae & Indian nightjar & Caprimulgus asiaticus(Latham, I790) & $\mathrm{R}$ \\
\hline 28. & Charadriidae & Red-wattled lapwing & Vanellus indicus (Boddaert, I783) & $\mathrm{R}$ \\
\hline 29. & Chloropseidae & Blue-winged leafbird & $\begin{array}{l}\text { Chloropsis cochinchinensis (Gmelin, JF, } \\
\text { I789) }\end{array}$ & $\mathrm{R}$ \\
\hline 30. & Ciconiidae & White stork & Ciconia ciconia (Swinhoe, I873) & W \\
\hline 31. & \multirow[t]{3}{*}{ Cisticolidae } & Ashy prinia & Prinia socialis (Sykes, I832) & V \\
\hline 32. & & Grey-fronted quail-dove & Geotrygon caniceps (Gundlach, 1852) & $\mathrm{R}$ \\
\hline 33. & & $\begin{array}{l}\text { Yellow-footed green } \\
\text { pigeon }\end{array}$ & Treron phoenicoptera (Latham, I790) & $\mathrm{R}$ \\
\hline 34. & \multirow[t]{3}{*}{ Columbidae } & Rock pigeon & Columba livia (Gmelin, I789) & $\mathrm{R}$ \\
\hline 35. & & Eurasian collared dove & Streptopelia decaocto (Frivaldszky, I838) & $\mathrm{R}$ \\
\hline 36. & & Spotted dove & Spilopelia chinensis (Scopoli, I786) & $\mathrm{R}$ \\
\hline 37. & Coraciidae & Indian roller & Coracias benghalensis (Linnaeus, I758) & $\mathrm{R}$ \\
\hline 38. & Corvidae & Jungle crow & Corvus macrorhynchos (Wagler, I827) & $\mathrm{R}$ \\
\hline
\end{tabular}


Table Continued.

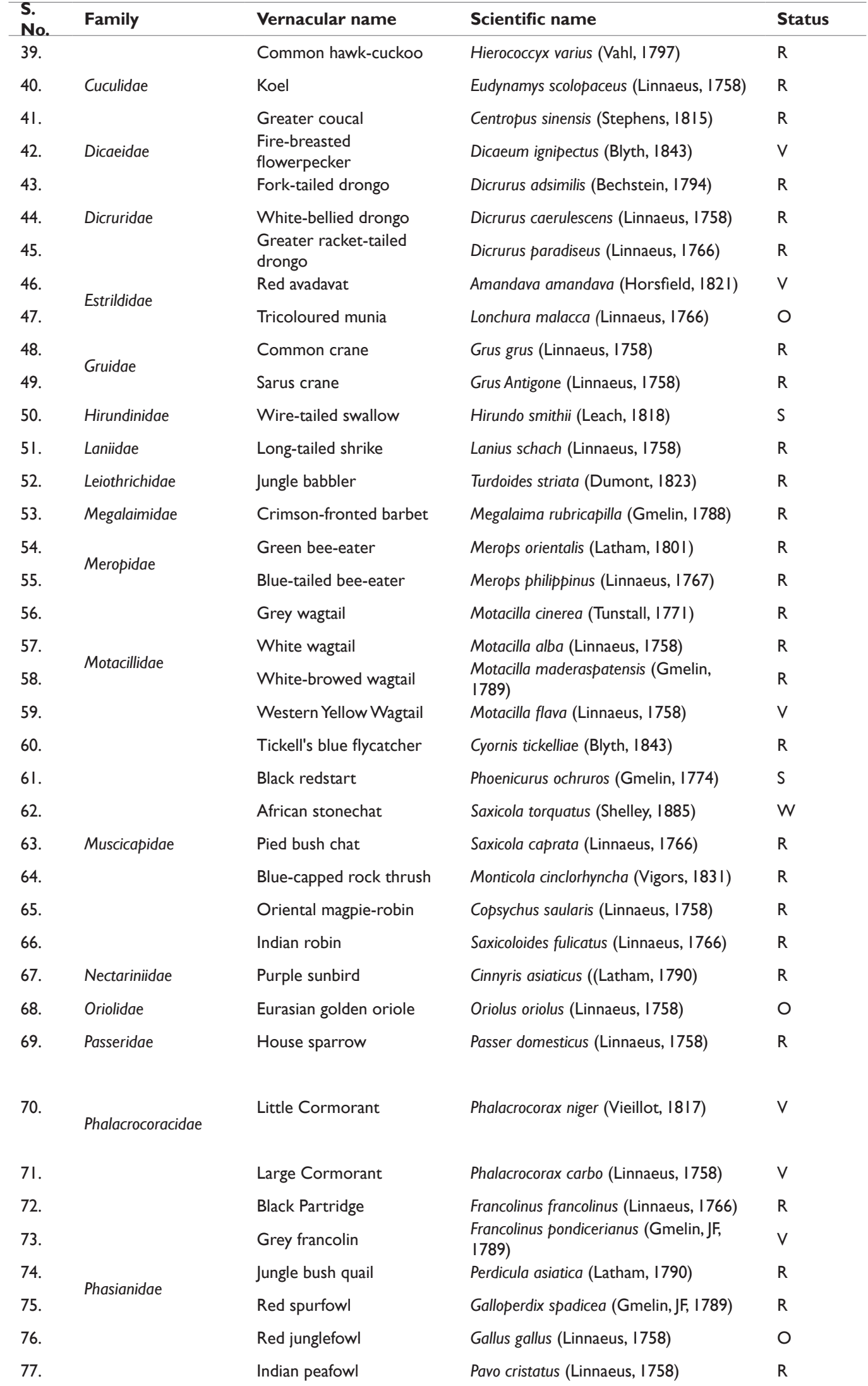


Table Continued.

\begin{tabular}{|c|c|c|c|c|}
\hline 78. & & Black-rumped flameback & Dinopium benghalense (Linnaeus, I758) & $\mathrm{R}$ \\
\hline 79. & Picidae & $\begin{array}{l}\text { Yellow fronted pied } \\
\text { woodpecker }\end{array}$ & Leiopicus mahrattensis (Latham, I80I) & $\mathrm{R}$ \\
\hline 80. & Pittidae & Indian pitta & Pitta brachyuran (Linnaeus, 1766) & $\mathrm{R}$ \\
\hline 81. & Ploceidae & Baya weaver & Ploceus philippinus (Linnaeus, I766) & $\mathrm{R}$ \\
\hline 82. & & Alexandrine parakeet & Psittacula eupatria (Linnaeus, I766) & $\mathrm{R}$ \\
\hline 83. & Psittacidae & Rose-ringed parakeet & Psittacula krameri (Scopoli, 1769) & $\mathrm{R}$ \\
\hline 84. & & Blossom-headed parakeet & Psittacula roseate ( Biswas, I95I) & $\mathrm{R}$ \\
\hline 85. & Pycnonotidae & Red-vented bulbul & Pycnonotus cafer ((Linnaeus, I766) & $\mathrm{R}$ \\
\hline 86. & Recurvirostridae & Black-winged stilt & Himantopus himantopus (Linnaeus, I758) & $\mathrm{R}$ \\
\hline 87. & Rhipiduridae & White-browed fantail & Rhipidura aureola (Lesson, I83I) & W \\
\hline 88. & Rostratulidae & Greater painted-snipe & Rostratula benghalensis (Linnaeus, I758) & $\mathrm{R}$ \\
\hline 89. & Scolobacidae & Common redshank & Tringa tetanus (Linnaeus, I758) & $\mathrm{R}$ \\
\hline 90. & & Common snipe & Gallinago gallinago (Linnaeus, 1758) & W \\
\hline 91. & Sittidae & Indian nuthatch & Sitta castanea (Lesson, I830) & S \\
\hline 92. & Strigidae & Eurasian eagle-owl & Bubo bubo (Linnaeus, I758) & O \\
\hline 93. & 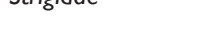 & Jungle owlet & Glaucidium radiatum (Tickell, I833) & O \\
\hline 94. & & Chestnut-tailed starling & Sturnia malabarica (Gmelin, JF, I789) & $\vee$ \\
\hline 95. & & Brahminy starling & Sturnia pagodarum ((Gmelin, JF, I789) & v \\
\hline 96. & Sturnidae & Pied myna & Gracupica contra (Linnaeus, I758) & $\mathrm{R}$ \\
\hline 97. & & Jungle myna & Acridotheres fuscus (Wagler, I827) & $\mathrm{R}$ \\
\hline 98. & & Common myna & Acridotheres tristis (Linnaeus, 1766) & $\mathrm{R}$ \\
\hline 99. & Threskiornithidae & White Ibis & Eudocimus albus (Linnaeus, I758) & $\mathrm{R}$ \\
\hline 100. & Timaliidae & $\begin{array}{l}\text { White-browed scimitar } \\
\text { babbler }\end{array}$ & $\begin{array}{l}\text { Pomatorhinus schisticeps (Hodgson, } \\
\text { 1836) }\end{array}$ & $\mathrm{R}$ \\
\hline I0I. & Upupidae & Hoopoe & Upupa epops (Linnaeus, 1758) & $\mathrm{R}$ \\
\hline
\end{tabular}

Table 12 Butterflies in the Study Area

$\begin{array}{llll}\text { Family } & \text { Scientific Name } & \text { Common name } & \text { Relative abundance } \\ \text { Papilionidae } & \text { Papilio polytes Linnaeus } & \text { Common Mormon } & \text { Common } \\ \text { Eieridae } & \text { Eurema hecabe Linnaeus } & \text { Common Grass yellow } & \text { Very Common } \\ & \text { Ixias Marianne Cramer } & \text { White orange tip } & \text { Common } \\ & \text { Danaus chrysippus Linnaeus } & \text { Plain Tiger } & \text { Common } \\ & \text { Danaus genutia Cramer } & \text { Striped Tiger } & \text { Common } \\ & \text { Phalantha phalantha Drury } & \text { Common Leopard } & \text { Fairy Common } \\ \text { Nymphalidae } & \text { Hypolimnas misippus Linnaeus } & \text { Danaid egg fly } & \text { Common } \\ & \text { Mycalesis perseus Fabricius } & \text { Common bush brown } & \text { Uncommon } \\ & \text { Cynthia cardui Linnaeus } & \text { Painted Lady } & \text { Uncommon } \\ & \text { Junonia hierta Fabricius } & \text { Yellow pansy } & \text { Common } \\ & \text { Junonia orithya Linnaeus } & \text { Blue pansy } & \text { Fairy Common }\end{array}$

Table 3 Reptiles and Amphibian in the Study Area

\begin{tabular}{lllll}
\hline S. no. & Family & Common Name & Scientific name & Schedule as IWPA, I972 \\
\hline I & \multirow{2}{*}{ Agamidae } & Common Garden Lizard & Calotes versicolor (Cuvier, 1817) & Not listed \\
2 & & Fan-Throated Lizard & Sitana ponticeriana (Cuvier, 1817) & Not listed \\
\hline
\end{tabular}


Table Continued.

\begin{tabular}{lllll}
\hline S. no. & Family & Common Name & Scientific name & Schedule as IWPA, I972 \\
\hline 3 & Bufonidae & Toad & Bufo bufo (Gray I825) & Not listed \\
4 & Chamaeleonidae & Indian chameleon & Chameleon calcaratus (Rafinesque, I8I5) & Schedule II \\
5 & Colubridae & Common Rat Snake & Ptyas mucosus (Linnaeus, I758) & Schedule II \\
6 & Crocodylidae & Crocodile & Crocodle crocodylus (Cuvier, 1807) & Schedule I; Part II ID \\
7 & Elapidae & Common Indian Krait* & Bungarus caeruleus (Schneider, I80I) & Schedule II \\
8 & Indian Cobra* & Naja naja (Linnaeus, I758) & Schedule II \\
9 & Gekkonidae & House Gecko & Hemidactylus flaviviridis (Ruppell, I835) & Not listed \\
10 & Pythonidae & Rock Python & Python molurus (Linnaeus, I758) & Schedule II \\
II & Scincidae & Brahminy Skink* & Mabuya carinata (Schneider, 180I) & Not listed \\
I2 & Varanidae & Indian Monitor & Varanus benghalensis (Daudin, I802) & Schedule II \\
I3 & Viperidae & Russel Viper* & Vipera russelli (Shaw \& Nodder, I797) & Schedule II \\
\hline
\end{tabular}

Table 14 Mammals in Study Area

\begin{tabular}{|c|c|c|c|c|}
\hline S. No. & Family & Scientific name & Common name & Status as per IWPA I 972 \\
\hline I. & \multirow{4}{*}{ Antilopinae } & Antilope cervicapra (Linnaeus, 1758) & Black buck & Schedule - I; Part -I; 2 \\
\hline 2. & & Boselaphus tragocamelus (Pallas, I766) & Blue bull & Schedule-III \\
\hline 3. & & Tetracerus quadricornis (de Blainville, I8I6) & Four horned Antilope & Schedule - I; Part -I; 8A \\
\hline 4. & & Cervus unicolor (Kerr, I792) & Sambhar & Schedule - III \\
\hline 5. & Bovidae & Gazella bennetti (Sykes, I83I) & Chinkara & Schedule - I; Part -I; 5B \\
\hline 6. & \multirow{4}{*}{ Canidae } & Canis aureus (Linnaeus, 1758) & Jackal & Schedule - II \\
\hline 7. & & Vulpes benghalensis (Shaw, I800) & Indian fox & Schedule - II \\
\hline 8. & & Cuon alpines (Pallas, $|8| \mathrm{I}$ ) & Wild Dog/Dhole & Schedule - II \\
\hline 9. & & Axis axis (Erxleben, I777) & Spotted deer & Schedule - III \\
\hline 10. & Circopthecidae & Macaca mulata (Zimmermann, I780) & Rhesus macaque & Schedule - II \\
\hline II. & Cotobidae & Presbytis entellus (Dufresne, I797) & Common Languor & Schedule - II \\
\hline 12. & \multirow[t]{2}{*}{ Einaceidae } & Hemiechinus aurutus (Gmelin, 1770) & Hedgehog & Schedule - IV \\
\hline 13. & & Panthera tigris (Linnaeus, I758) & Tiger & Schedule - I; Part-I; 39 \\
\hline 14. & Felidae & Panthera pardus (Linnaeus, I758) & Panther/Leopard & Schedule - I; Part-I; I6B \\
\hline 15. & & Felis chaus (Schreber, I777) & Common Jungle cat & Schedule - II \\
\hline 16. & Herpestidae & $\begin{array}{l}\text { Herpestes edwardsii (É. Geoffroy Saint-Hilaire, } \\
\text { I8I8) }\end{array}$ & Common Mongoose & Schedule - II \\
\hline 17. & Hyaenidae & Hyaena hyaena (Linnaeus, I758) & Striped hyena & Schedule - III \\
\hline 18. & Hystricidae & Hystrix indica (Kerr, I792) & Common Indian Porcupine & Schedule IV \\
\hline 19. & Leporidae & Lepus nigricollis (F. Cuvier, I823) & Common Indian Hare & Schedule IV \\
\hline 20. & Manidae & Manis crassicaudata (É. Geoffroy, I803) & Scaly ant eater & Schedule-I; Part-I; 28 \\
\hline 21. & \multirow{2}{*}{ Muridae } & Bandicota benghalensis (Gray, 1835) & Field Rat & Not listed \\
\hline 22. & & Golunda ellioti (Gray, I837) & The Indian bush rat & Not listed \\
\hline 23. & Mustelidae & Mellivora capensis (Schreber, 1776) & Indian Ratel/Honey Badger & Schedule-I; Part-I; 29 \\
\hline 24. & \multirow[t]{2}{*}{ Pteropodidae } & Cynopterus sphinx (Vahl, 1797) & Shot nosed fruit bat & ScheduleV \\
\hline 25. & & Pteropus giganteus (Brünnich, 1782) & Indian Flying fox & Schedule IV \\
\hline 26. & Sciuridae & Funambulus Pennanti (Wroughton, 1905) & Common 5 Striped Squirrel & Schedule IV \\
\hline 27. & Suidae & Sus scrofa (Linnaeus, I758) & Wild Boar & Schedule - II \\
\hline 28. & Ursidae & Melursus ursinus (Shaw, 179I) & Sloth Bear & Schedule-I; Part-I; 3IC \\
\hline
\end{tabular}


Table 15 List of Fishes reported from the Study area

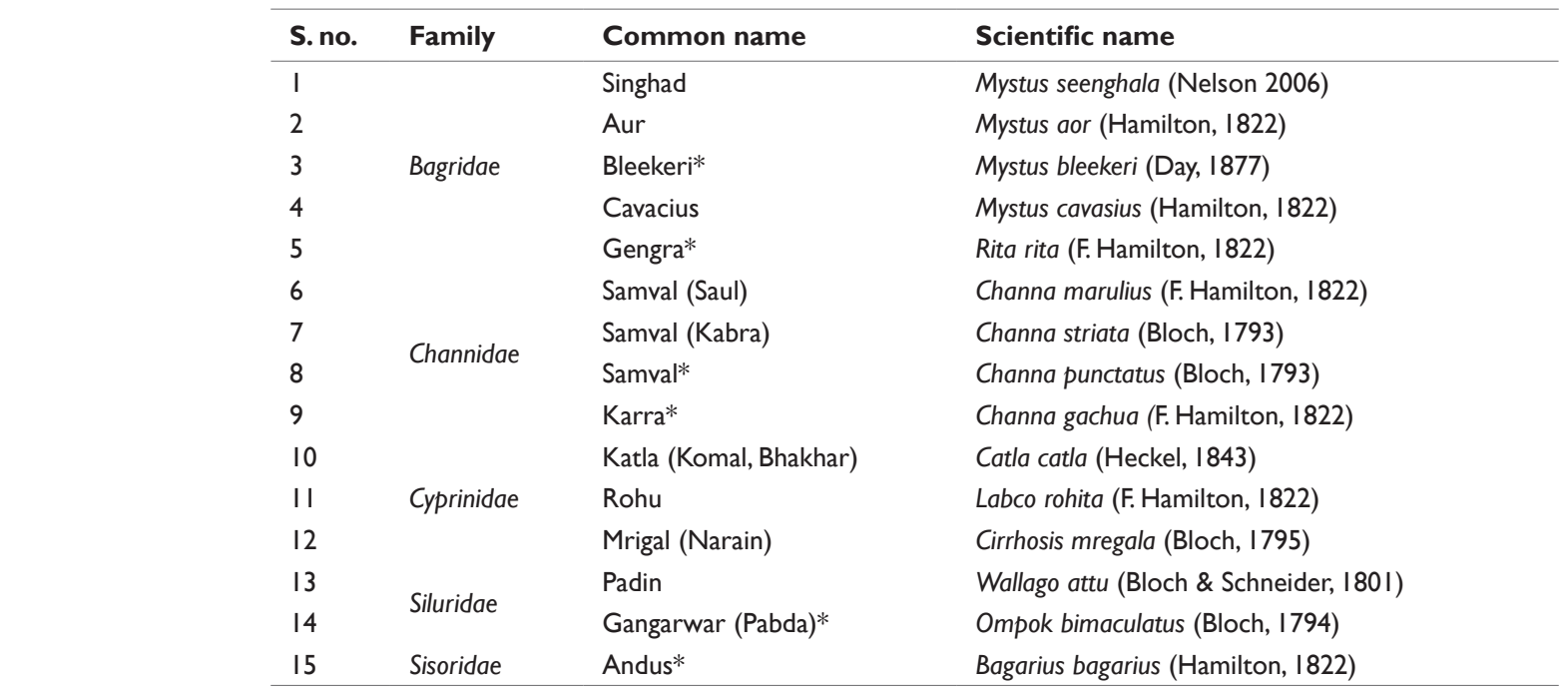

*not seen directly

Table 16 List of Schedule -I Fauna observed During the Survey. Colors are indicating the state of conservation in accordance with IUCN

\begin{tabular}{|c|c|c|c|c|c|}
\hline S. no. & Scientific name & Common name & $\begin{array}{l}\text { Schedule as per (WPA, } \\
\text { 1972) }\end{array}$ & IUCN category & CITES listing \\
\hline I & Panthera tigris & Tiger & Schedule-I; Part-I; 39 & $\begin{array}{l}\text { Endangered } \mathrm{A} 2 \mathrm{abcd} ; \mathrm{Cl} \text { ver } \\
3.1\end{array}$ & Appendix I \\
\hline 2 & Manis crassicaudata & Scaly ant eater & Schedule-I; Part-I; 28 & Endangered $A 3 d+4 d$ ver 3.1 & Appendix I \\
\hline 3 & Panthera pardus & Panther/Leopard & Schedule-I; Part-I; I6B & Vulnerable $\mathrm{A} 2 \mathrm{~cd}$ ver 3.1 & Appendix I \\
\hline 4 & Melursus ursinus & Sloth Bear & Schedule-I; Part-I; 3 IC & Vulnerable $A 3 c$ ver 3.1 & Appendix I \\
\hline 5 & Tetracerus quadricornis & Four horned Antilope & Schedule-I; Part-I; 8A & Vulnerable $\mathrm{C} 2 \mathrm{a}(\mathrm{i})$ ver 3.1 & Appendix III \\
\hline 6 & Gazella gazellabennetti & Chinkara & Schedule-I; Part-I; 5B & Least Concern ver 3.1 & Appendix III \\
\hline 7 & Antilope cervicapra & Black buck & Schedule-I; Part-I; 2 & Least Concern ver 3.1 & Appendix III \\
\hline 8 & Mellivora capensis & Indian Ratel & Schedule-I; Part-I; 29 & Least Concern ver 3.1 & Appendix III \\
\hline 9 & Pavo cristatus & Indian Peafowl & Schedule-I; Part-III; I I & Least Concern ver 3.1 & Not listed \\
\hline 10 & Crocodle crocodylus & Crocodile & Schedule I; Part II ID & Not Assessed yet & Not listed \\
\hline
\end{tabular}
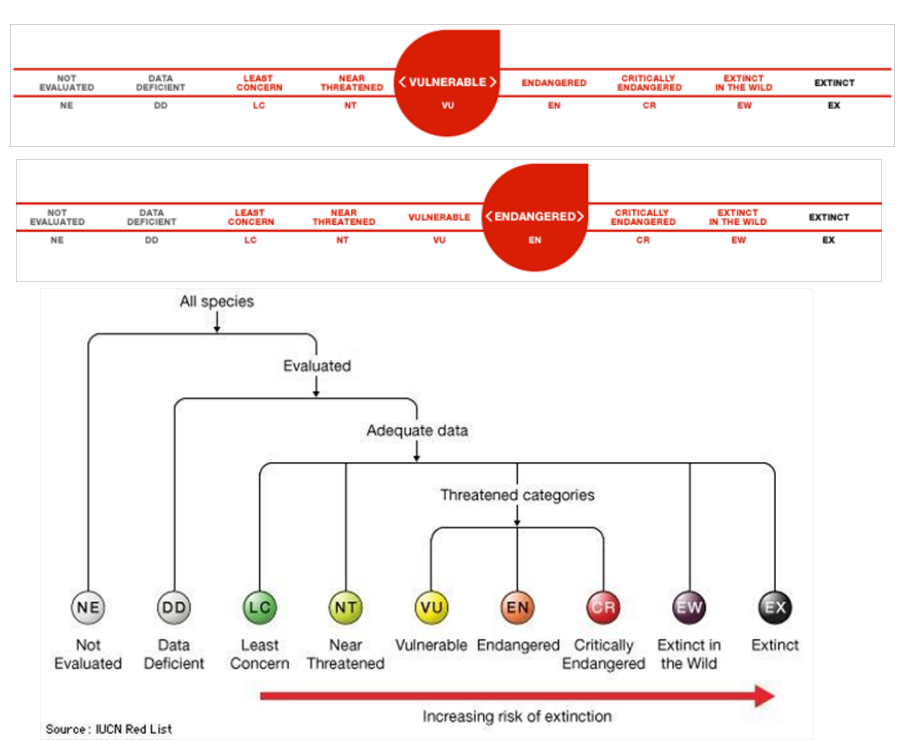

Figure 10 Representation of Risk of Extinction as per IUCN.

\section{Recommendations and conclusion}

The study area is ecologically sensitive having protected and reserved forest and notified wildlife sanctuary. The railway track is passing through Ratapani Wildlife Sanctuary which has rich biodiversity and endangered species. These wildlife areas are classified into semi-arid wildlife zone-IVB Gujarat Rajputana under Roger and Pawar classification. The sanctuary is inhabited by all the usual animals of the region, such as tiger (Panthera tigris) leopard (Panthera pardus), wolf (Canis lupus), Jackal (Canis aureus), Indian fox (Vulpes bengalensis), Striped hyena (Hyaena hyaena) Sloth bear (Melursus ursinus) among carnivores and spotted deer (Axis axis), Sambhar (Cervus unicolor), Nilgai (Boselaphus tragocamelus), Chinkara (Gazella bennetti), Wild pig (Sus scrofa), Chowsingha (Tetracerus quadriconis) and Blackbuck (Antelope cervicapra), amongst herbivores. Apart from these, crocodiles/gharials can also be seen in Ratapani Wildlife Sanctuary. Ratapani Wildlife Sanctuary contains 129 tree species, 73 herbs and shrubs species, 33 climbers and parasites, 35 grasses and bamboo species, 35 mammals, 205 birds, 14 fish, 33 reptiles and 10 species of amphibians have been recorded in Ratapani Wildlife Sanctuary. 
Panthera tigris (Tiger) and Manis crassicaudata (Scaly ant eater) are endangered species listed by IUCN and protected under Schedule -1 as per Wildlife Protection Act 1972. Panthera pardus (Leopard), Melursus ursinus (Sloth Bear) and Tetracerus quadricornis (Four horned Antilope) are vulnerable species listed by IUCN and protected under Schedule -1. Other species protected under schedule -1 are Gazella gazellabennetti (Chinkara), Antilope cervicapra (Black buck), Mellivora capensis (Indian Ratel), Crocodle crocodylus (Crocodile) and one bird Pavo cristatus (Indian Peafowl). The illegal tree cutting by villagers and contractors was observed during study. The 8 tiger death was reported by RFO last year (2016-17) on Railway track. The major reason was in search of food i.e. Monkey. The people travelling in train are disposing food items and people working in pantry are also used to dispose the waste food in the forest. The food item attract to monkeys and they are killed by running train on railway track, the blood and meat of money attract to tigers/panthers and also they were killed by running train on railway track mostly in night.

It is strongly recommended to prepare the conservation plan for schedule -1 Fauna (listed 9 animals and 1 bird) and it is ensure to implement the conservation plan during construction and operation phase of railway track. Moreover, there is an urgent need of public awareness for the importance of wildlife, as illegal hunting, killing or capturing of wild animals was recorded from locals living in the forest and nearby villagers. People coming from outside are giving the greed of money and other necessary provision to villagers for hunting. It's an environmental crime against the natural resources. ${ }^{50-60}$

\section{Acknowledgements}

None.

\section{Conflict of interest}

Authors declare there is no conflict of interest in publishing the article

\section{References}

1. Anderson T. An enumeration of the Indian species of Acanthaceae. Journal of Linnaean Society. 1867;9:425-454.

2. Jain SK, Rao RK. An assessment of threatened plants of India. Bot Surv of India. 1983.

3. Dixit RD. A census of the Indian Pteridophytes. Flora of India Series 4. Botanical Survey of India, Howrah (Calcutta): 1984.

4. Wilson DE, Reeder DM, editors. Mammal Species of the World. A Taxonomic and Geographic Reference. 3rd ed. Johns Hopkins University Press, Baltimore; 2005.

5. Kumar A. Butterfly (Lepidoptera: Insecta) Diversity from Different Sites of Jhagadia, Ankleshwar, District-Bharuch, Gujarat. Oct Jour Env Res. 2013;1(1):9-18.

6. Ashok K, Meena S, Savita G. The Biodiversity At Sandi Bird Sanctuary, Hardoi With Special Reference to Migratory Birds. Oct Jour Env Res. 2013;1(3):173-181

7. Hutto RL, Pletsechel SM, Hendrick P. A fixed radius point count method for non-breeding season use. The Auk. 1986;103:593-602.

8. Welsh HH, 1987. Monitoring herpetofauna in woodlands of north western California and south west Oregon: a comparative strategy. In: Plumb TR, Pillsbury NH, editors. Multiple-use Management of California's Hardwood Resources. USDA Forest Service General Technical Report PSW-100. Pacific Southwest Research Station. Albany, CA; 1987. p. 203-213.
9. Thommpson ID, Davidson IJ, O’ Donnell S, et al. Use of track transects to measure the relative occurrence of some arboreal mammals in uncut forest and regeneration stands. Canadian Journal of Zoology. 1989;67(7):1816-1823.

10. Welsh $\mathrm{H}$, Lind AJ. The structure of the herpetofaunal assemblage in the Douglas-fir/hardwood forests of northwestern California and south western Oregon. 1991. p. 395-411.

11. Allen L, Engeman R, Krupa H. Evaluation of three relative abundance indices for assessing dingo population. Wildlife Research. 1996;23(2):197-205.

12. Misra R. Ecology Workbook. Scientific Publishers; 2013. p. 31-45.

13. Bentham G, Hooker JD. Genera plantarum. L Reeve and Co., London; 1862-1883.

14. Hunter WW. Statlstlcal Account of Assani. Vol II Trubner and Co; 1879.

15. Ghosh SR, Ghosh B, Biswas A, et al. The Pteridophytic Flora of Eastern India. Flora of India Series 4, Botanical Survey of India, Kolkat. 2004;1:1-591.

16. Lushington AW. Vernacular list of trees, shrubs and woody clarnbers of the Madras Presidency. Govt. Press, Madras; 1915.

17. Wilson DE, Reeder DM, editors. Mammal Species of the World a Taxonomic and Geographic reference. 2nd ed. Smithsonian Institution Press, Washington and London; 1993.

18. BirdLife International. Threatened Birds of the World. Lynx Edicions and BirdLife International, Barcelona and Cambridge, UK; 2000. 852 p.

19. BirdLife International. Threatened Birds of the World 2004. CD-ROM. BirdLife International, Cambridge, UK; 2004a.

20. BirdLife International. State of the World's Birds 2004-Indicators for our changing world. BirdLife International, Cambridge, UK; 2004b.

21. BirdLife International. The BirdLife checklist of the birds of the world, with conservation status and taxonomic sources. 2010.

22. Ashok K, Meena S. Diversity of medicinal Plants in Uttarakhand and their conservation Strategy with special reference to Orchids. Proceeding of National Conference on Environmental Health: Challaneges and Management, organized by Pt. Deendayal Upadhyay Govt. PG College Rajajipuram, Lucknow; 2012. p. 20-21,139-142.

23. Ashok K, Aggarwal SG. Ecology and Biodiversity status of Sachin gidc and its surroundings with Special reference to Conservation measures for Indian Peafowl (Pavo cristatus) schedule -I Bird species. Oct Jour Env Res. 2014;2(1):82-100.

24. Ashok K, Aggarwal SG. Study of Common Property Resources (CPR) With Special Reference to Water and Biological Resources at projected area near Village Ninat, Bardoli, District-Surat. Oct Jour Env Res. 2013;1(4):319-331.

25. World Conservation Monitoring Centre. The Conservation of Biological Diversity. WCMC., IUCN, Cambridge, UK; 1988.

26. IUCN. IUCN Red List Categories. Prepared by the IUCN Species Survival Commission. IUCN, Gland, Switzerland; 1994.

27. World Conservation Monitoring Centre. Global Biodiversity: Earth's living resources in the 21st Century. In: Groombridge B, Jenkins MD, editors. World Conservation Press, Cambridge; 2000.

28. IUCN. IUCN Red List Categories and Criteria: Version 3.1. IUCN Species Survival Commission. IUCN, Gland, Switzerland and Cambridge, UK; 2001.

29. IUCN. Guidelines for Application of IUCN Red List Criteria at Regional Levels: Version 3.0. IUCN Species Survival Commission. IUCN, Gland, Switzerland and Cambridge, UK; 2003. 
30. IUCN. Red List of Threatened Species. 2008.

31. IUCN. Guidelines for Using the IUCN Red List Categories and Criteria. version 8.1, prepared by the Standards and Petitions Subcommittee of the IUCN Species Survival Commission; 2010.

32. Ohasi H. Flora of Eastern Himalaya. Third Report. University Museum of University of Tokyo Bulletin. 1975;8:1-458.

33. Jain SK. Dictionary of Indian folk medicine and ethnobotany. Deep publications, New Delhi; 1991.

34. Jain SK. Medicinal Plants Nation Book Trust. New Delhi; 1968.

35. Jain SK, Sastry ARK. Safeguarding Plant diversity in threatened Natural Habitats. In: Anthony VH, editor. Conservation of Threatened Natural Habitats. African nat Sci Prog Report 92; 1984.

36. Nayar MP, Sastry ARK. Red Data Book of Indian Plants. Botanical Survey of India, Calcutta. 1987.

37. Nayar MP, Sastry ARK. Red Data Book of Indian Plants. Botanical Survey of India, Calcutta. 1988.

38. Nayar MP, Sastry ARK. Red Data Book of Indian Plants. Botanical Survey of India, Calcutta. 1990

39. Oldfield S, Lusty C, MacKinven A. The World List of Threatened Trees. World Conservation Press, Cambridge; 1998.

40. Kholia BS, Bhakuni K. Western Himalaya a new range of distribution for a critically endangered fern, Dryopsis manipurensis (Bedd.) Holttum \& PJ Edwards. Nelumbo Bulletin of the Botanical Survey of India. 2009;51:245-248.

41. Nayar MP. Endemism and patterns of distribution of endemic genera (Angiosperms) in India. J Econ Tax Bot. 1980;1:99-110.

42. Ahmedullah M, Nayar MP. Endemic Plants of the Indian Region. Bot Surv of India, Calcutta; 1986.

43. Ahmedullah M, Nayar MP. Endemic Plants of the Indian region. Botanical Survey of India, Calcutta; 1987. 147 p.

44. Jain SK. The Problem of Endangered Species. Concepts, Problems and Solutions. In: Singh KP, Singh JS, editors. Tropical Ecosystems. Ecolosv and Management. Iiley Eastern iimited, New delhi; 1992. p. 69-80.

45. Nayar MP. Hotspots of Endemic Plants of India, Nepal and Bhutan. Thiruvananthapuram: Tropical Botanical Garden and Research Institute; 1996. 204 p.

46. Vijaya Sankar R, Ravikumar R, Ganesh Babu NM. On the collection of a Peninsular Endemic, Barleria stocksii (Acanthaceae), after a century. Zoo's Print Journal. 2005;20(3):1820.
47. Nautiyal DC, Sharma SK, Pandit MK. Notes on the taxonomic history, rediscovery and conservation status of two endangered species of Ceropegia (Asclepiadaceae) from Sikkim Himalaya. Journal of Botanical Research Institute Texas. 2009;3(2):815-822.

48. Nautiyal DC, Sharmaand SK, Pandit MK. Notes on the taxonomic history of two rare species of Begonia (Begoniaceae) from Sikkim Himalaya and their conservation. Journal of Botanical Research Institute Texas. 2009;3(2):823-830.

49. Shendage SM, Yadav SR. Revision of the Genus Barleria (Acanthaceae) in India. Rheedea. 2010;20(2):81-230.

50. APHA. Standard methods for the examination of water and waste water. American Public Health, Association, New York; 1971.

51. Batten SD, Clarke R, Flinkman J, et al. CPR sampling: the technical background, material and methods, consistency and comparability. Progress in Oceanography. 2003;58(2-4):193-215.

52. Colebrook JM. Continuous Plankton records: methods of analysis, 1950-59. Bulletins of Marine Ecology. 1960;5:51-64

53. Edmondson WT. A simplified method for counting phytoplankton. In: Vollenmeider RE, editor. A manual on methods for measuring primary production in Aquatic environments. Balckwell Sci. Pub, Oxford; 1974 p. 14-16.

54. Gamble JS. The Flora of Presidency of Madras 2. Botanical Survey of India, Culcutta; 1924. 743 p.

55. Jain SK, Sastry ARK. Threatened plants of India. A State of the Alf Report Bot Surv of India, New Delhi; 1980.

56. Ashok K. Environmental Management Plan for Chemical Industries Especially Resin Manufacturing Unit. Oct Jour Env Res. 2014;2(3):262-273

57. Lackey JB. The manipulation and counting of river plankton and changes in some organisms due to formalin preservation. US Public Health Reports. 1938;53(47):2081-2093.

58. Vollenweider RA, editor. A Manual of Methods For Measuring Primary Production in Aquatic Environment. IBP Handbook No. 12, Blackwell Scientific Publications; 1969. p. 213.

59. Welch FS. Limnological Methods. McGraw Hill Book Co Inc, New York; 1948.

60. Jain SK. Rare and Endangered Specles: Observation on rare, imperfectly known endemic plants. In the sacred groves of Western Maharashtra. Calcutta. Bot Sur of India. 1983:169-178. 